\title{
Mordecai's Royal Vestments: Princely and/or Priestly?
}

\author{
JoshuA Joel Spoelstra (UNIVERSITY OF STELlENBosCh)
}

ABSTRACT

This essay examines the function of clothing and related accoutrements in the book of Esther. The motif of dressing and undressing oneself or another signals a shift in the investment or divestment of power and status. Identity, agency, and authority are also signified by vestments and appurtenances. Through synchronic and diachronic exegetical methodologies, Mordecai's regalia of Esth 8:15 is the focus of this essay. This regalia evokes both princely and priestly ideology; therefore, the regalia is a significant symbol for the diasporic, post-monarchic Jewish people in the Persian period. The closest post-exilic analogue to Mordecai's royal vestments and accessories is the diarchic portending prophecies of Zech 6; thus, extrapolations are made accordingly. Ultimately, a definite determination of the significance of Mordecai's regalia cannot be made; nevertheless, the royal vestments are likely imbued with a complex intention-to ignite the imagination of the possibilities for the Jewish people's open-ended future.

KEYWORDS: Clothing, Esther, Mordecai, Palace, Priestly, Tabernacle

\section{A. INTRODUCTION}

Clothing is an often overlooked - though more recently emerging-field of study, important in the interpretation of biblical material. ${ }^{1}$ Herein, the function and performance of clothing and its related accoutrements along with the act of robing and disrobing in the book of Esther (MT) will be examined. The present presupposition is that characters and plots are vividly enhanced by the garments and accessories worn. In particular, special attention will be given to Mordecai

* Submitted: 25/08/2018; peer-reviewed: 08/03/2019; accepted: 11/03/2019. Joshua Joel Spoelstra, "Mordecai's Royal Vestments: Princely and/or Priestly?," Old Testament Essays 32 no. 1 (2019): 174-196. DOI: https://doi.org/10.17159/2312-3621/ 2019/v32n1a10.

1 Recent studies include Alicia J. Batten, Carly Daniel-Hughes, and Kristi UpsonSaia, eds., Dressing Judeans and Christians in Antiquity (Burlington, VT: Ashgate, 2014); Megan Cifarelli and Laura Gawlinski, eds., What Shall I Say of Clothes? Theoretical and Methodological Approaches to the Study of Dress in Antiquity, SPAAA 3 (Boston: Archaeological Institute of America, 2017); Antonios Finitsis, ed., Dress and Clothing in the Hebrew Bible: "For All Her Household Are Clothed in Crimson", LHBOTS 679 (London: Bloomsbury T\&T Clark, Forthcoming). 
being arrayed with regalia (Esth 8:15), in order to determine its full range of significance.

It shall be argued that Mordecai's regalia in Esth 8:15 signals royal ideology. ${ }^{2}$ On the one hand, the royal aspect is princely, as it resonates synchronically within the book of Esther; on the other hand, the royal aspect is priestly, which reverberates diachronically in the Pentateuch. The complimentary melding of synchronic and diachronic exegesis utilised yields a multivalent discourse or multidimensional mosaic of, in this case, clothing in the book of Esther. ${ }^{3}$ Further, Mordecai's regalia, especially his crown being analogous to the one in Zech 6, portend various possibilities of identity and agency in the post-exilic existence of Jewish leadership in Yehud.

To argue the thesis, the following stages of presentation and methodologies are thus arranged. First, an inventory of clothing in the book of Esther is made, and, in concert, a panorama of the issue of robing and disrobing is presented. Second, Mordecai's regalia in Esth 8:15 is juxtaposed with similar palatial materials in Esth 1:6, and a loose Israelite analogue is expounded; in addition, the vestments and accoutrements of Esth 8:15 are also comparatively examined in relation to the materiality of the high priest's vestments and the tabernacle fabrics and décor, an association analogous to the contents of Esth 1:6 and 8:15. In these sections, the book of Esther is methodologically approached via narrative criticism and synchronic linguistic analysis. ${ }^{4}$ Third, the princely and priestly ideology, alluded to by the foregoing textual analysis, is extrapolated. Fourth, the princely-priestly hybridity suggested by Mordecai's regalia is located in the diasporic, post-monarchic milieu, during the Persian Empire; this setting is brought into dialogue with other resonant post-exilic biblical material, specifically Zech $6^{*}$. These latter two sections, which directly address the thesis, is a diachronic analysis, specifically employing the tradition-historical method. ${ }^{5}$ Finally, a summary of findings and statements of conclusion is submitted.

2 For ideological criticism, see e.g. Eryl W. Davies, Biblical Criticism: A Guide for the Perplexed (London: Bloomsbury T\&T Clark, 2013), 64-82; David Jobling and Tina Pippin, Ideological Criticism of Biblical Texts (Atlanta: Scholars Press, 1992).

3 Louis C. Jonker, Exclusivity and Variety: Perspectives on Multidimensional Exegesis, CBET 19 (Kampen: Kok Pharos, 1996).

4 See e.g. Jerome T. Walsh, Old Testament Narrative: A Guide to Interpretation (Louisville: Westminster John Knox, 2009); Yairah Amit, Reading Biblical Narratives: Literary Criticism and the Hebrew Bible, trans. Yael Lotan (Minneapolis: Fortress, 2001); D.F. Tolmie, Narratology and Biblical Narratives: A Practical Guide (London: International Scholars, 1999); Shimon Bar-Efrat, Narrative Art in the Bible, trans. Dorothea Shefer-Vanson with S. Bar-Efrat, JSOTSup 70 (Sheffield: Almond, 1989).

5 See e.g. Robert A. Di Vito, "Tradition-Historical Criticism," in To Each Its Own Meaning: An Introduction to Biblical Criticisms and their Applications, $2^{\text {nd }}$ ed., eds. Steven L. McKenzie and Stephen R. Haynes (Louisville: Westminster John Knox, 


\section{B CLOTHING IN ESTHER}

Initially, the clothing of each character in the book of Esther will be surveyed. Next, a corresponding survey will identify the acts of donning clothing on a character's own personage or upon another. This assessment will underscore who the main characters are and their association with the main events as well as to provide the necessary background to argue the thesis.

\section{The Characters' Clothing}

Clothing invariably denotes status or a change of status. ${ }^{6}$ In the book of Esther, the characters who are integrally connected with clothing and/or accessories are explicitly registered - they are Ahasuerus, Vashti, Haman, Esther, and Mordecai. It is the two Jewish personages, moreover, whose vestments come into focus most.

\section{1a Ahasuerus}

King Ahasuerus's clothing is never explicitly described or narratively foregrounded. Alternatively, the king's symbols of royalty mentioned are his

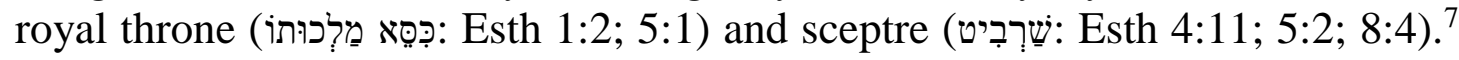
The closest clothing connoting item of Ahasuerus mentioned is his signet ring

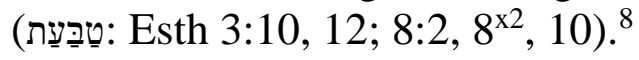

\section{1b Vashti}

Like Ahasuerus, only a royal decorative item is ascribed to adorn Queen

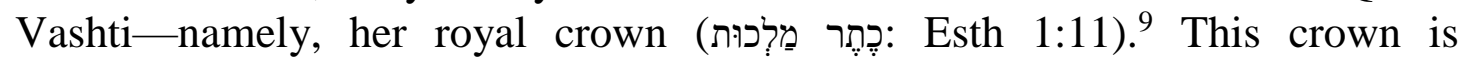
foregrounded when Ahasuerus bids her to appear before him and his company wearing it, which she does not. One interpretation surmises that Ahasuerus meant

1999), 90-104; Magne Sæbø, On the Way to Canon: Creative Tradition History in the Old Testament, JSOTSupp 191 (Sheffield: Sheffield Academic, 1998); Walter E. Rast, Tradition History and the Old Testament, ed. Gene M. Tucker, GBS (Philadelphia: Fortress, 1972).

$6 \quad$ Sandra Beth Berg, The Book of Esther: Motifs, Themes and Structure, SBLDS 44 (Missoula, MT: Scholars Press, 1979), 61-72.

7 This term for sceptre is found only in the book of Esther, differing from the more conventional שֶָָׁ (Gen 49:10; Num 24:17; Ps 45:6²; 125:3; Isa 14:5; Ezek 19:14;

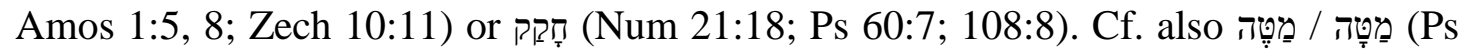
110:2; Jer 48:17).

8 Other than these references in the book of Esther, טַב a signet/finger ring is found in Gen 41:42, Num 31:50, and Isa 3:21. Cf. in Gen 38:18, 25; Exod 28:36; 35:22; 39:6, 30; Jer 22:24; Ezek 28:12; Hag 2:23; see also Dan 6:17.

9 This term for crown is found only in Esth $1: 11 ; 2: 17$; 6:8. See Alison Salvesen,

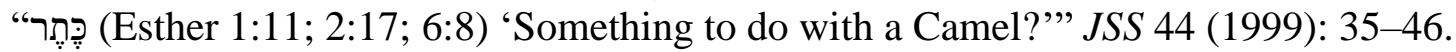


for Vashti to present herself wearing only her crown. ${ }^{10}$ Regardless, Vashti's refusal leads to her replacement.

\section{1c Haman}

The only item Haman is explicitly narrated as wearing is Ahasuerus's ring (טַבַַּ: Esth 3:10 [8:2]). Haman uses the ring to authorise an edict which he himself authors (Esth 3:12). Though Haman fantasises about wearing a royal garment (and crown $?^{11}$ ) previously worn by the monarch, this is instead destined for Mordecai (Esth 6).

\section{1d Esther}

Esther, upon becoming queen, wears a royal crown ( Additionally, when meeting the king in his throne room, Queen Esther wears her royal garments (מָלכוּ: Esth 5:1). This term is not descriptive of actual clothing, e.g. its design or materiality; rather, it bespeaks her royal status, for it is a regal adjective. $^{12}$

\section{1e Mordecai}

Mordecai's clothing is itemised in the narrative to reflect his grieving, honouring, and elevation. The types of clothing are, respectively, sackcloth (Esth 4:1-4), a king's robe (and crown? [Esth 6:8-11]), and auxiliary regalia (Esth 8:15): "royal robes of blue and white, with a great golden crown and a mantle of fine linen and purple" (NRSV). ${ }^{13}$

These outfits will be examined more closely below (B 2), especially the

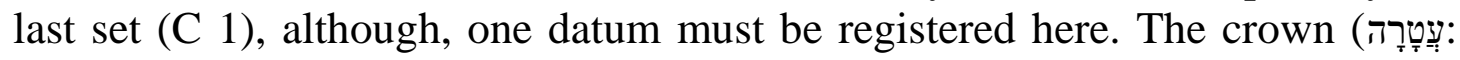
Esth 8:15) which Mordecai wears is a different term from all other crowns previously mentioned in the book of Esther (ภֶֶ: Esth $1: 11 ; 2: 7 ; 6: 8) .{ }^{14}$ In

10 So Esth Rab. 3:13-14.

11 The ambiguity of the crown and its placement will be fully addressed below (B 2c).

12 Jon D. Levenson (Esther, OTL [Louisville: Westminster John Knox, 1997], 89) notes: "The Talmudic authority Rabbi Hanina [b. Meg. 15a] interpreted the absence of any word for robes in the Hebrew to 5:1 (literally, 'Esther donned royalty') to mean that the Holy Spirit clothed her so that she spoke through prophetic inspiration."

13 In Tg. Esth. I and II a necklace is mentioned instead of a crown (Bernard Grossfeld, The Two Targums of Esther: Translated, with Apparatus and Notes, ArBib 18 [Collegeville, MN: Liturgical Press, 1991] 82, 186); cf. Dan 5:7, 16, 29; 1 Esdr 3:6.

14 Incidences of עִ עִ include: 2 Sam 12:30 // 1 Chr 20:2; Job 19:9; 31:36; Ps 21:4; Prov 4:9; 12:4; 14:24; 16:31; 17:6; Song 3:11; Isa 28:1, 3, 5; 62:3; Jer 13:18; Lam 5:16; Ezek 16:12; 21:31; 23:42; Zech 6:11, 14. Lewis B. Paton (A Critical and Exegetical Commentary on The Book of Esther, ICC [Edinburgh: T\&T Clark, 1976], 279), noting the lexical disparity, proffers "the idea is the same." 
addition, Mordecai also wears Ahasuerus's signet ring, the king having retrieved it from Haman (Esth 8:2, 8, 10).

\section{The Act of Robing and/or Disrobing Oneself and/or Another}

The act of robing and disrobing is often just as significant as the clothing itself. In the book of Esther, characters both clothe themselves and others; and, complicatedly, sometimes the dressing of another person is done reluctantly or even unsuccessfully. The act of donning different types of clothes denotes that a status change is taking place, along with the related investment or divestment of power for the status in view. ${ }^{15}$

\section{2a Ahasuerus}

Ahasuerus effectively strips the queen's crown from Vashti and gives it to Esther instead. ${ }^{16}$ Ahasuerus removes (סור: Esth 3:10) his signet ring from his own hand and gives it to Haman; later he removes (סור: Esth 8:2) it from Haman to bestow it upon Mordecai. These actions symbolically demonstrate how, as king (possessing throne and sceptre), Ahasuerus has the power to select and reject his queen and his prime minister, endowing and revoking the symbolic items thereof.

\section{2b Esther}

Esther's robing activity is narratively foregrounded in two instances; the first is her unsuccessful attempt to dress Mordecai, and the second is when she arrays

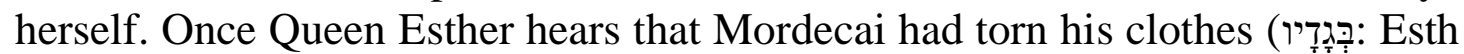
4:1), exchanging them for sackcloth and ashes, she sends him new garments

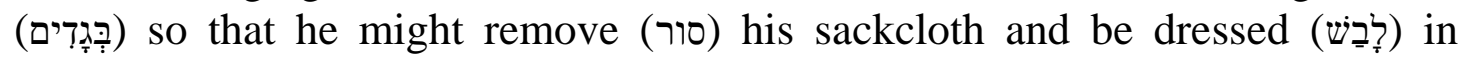

15 Cf. Michael J. Chan, "Joseph and Jehoiachin: On the Edge of Exodus," ZAW 125 (2013): 566-77; Thomas Römer, "From Deuteronomistic History to Nebiim and Torah" in Making the Biblical Text: Textual Studies in the Hebrew and Greek Bible, ed. Innocent Himbaza, OBO 275 (Fribourg: Academic Press; Göttingen: Vandenhoeck \& Ruprecht, 2015), 8.

16 No verbs directly describe this; indirectly, instead, the queenship was to be given (נֵָּן: Esth 1:19) to another, and eventually the royal crown is set (שים: Esth 2:17) on Esther's head. 
appropriate attire (Esth 4:4b). ${ }^{17}$ Mordecai refusing, ${ }^{18}$ Esther is unable to restore Mordecai's noble, dignified status by elevating his raiment.

Whereas Esther could not alter events by exchanging Mordecai's clothes, she does change events by dressing herself up. When Esther resolves to confront

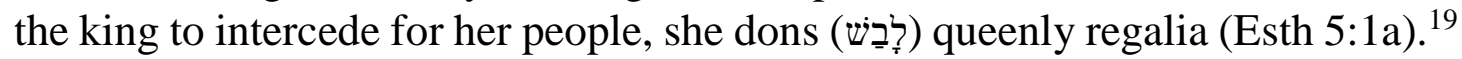
It must be inferred that Esther was wearing something more ordinary

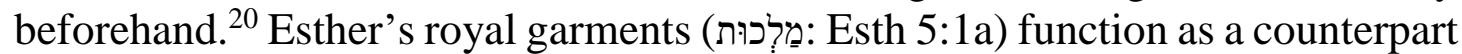

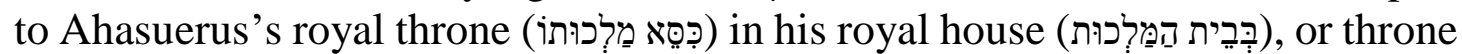
room (Esth 5:1b). Her clothing now harmonising with the king's status, ${ }^{21}$ Esther is offered up to half Ahasuerus's kingdom (מַלְכוּת: Esth 5:3, 6; 7:2). ${ }^{22}$

\section{2c Haman}

Though Haman desires to be clothed by a noble officer in a royal robe (and crown?) previously worn by the king, he, as that noble officer, instead clothes Mordecai with the same. Averse as he may be to enact this programme for Mordecai-enemies as they are (Esth 3:10; 7:6; 8:1; 9:10, 24)-Haman reluctantly does so nonetheless because the king has commanded it (Esth 6:10). Thus, what Esther is unable to do for Mordecai, Haman must do: (re)clothe him,

17 Levenson (Esther, 78-79) observes that, "given her ignorance of the cause of his public mourning, her extreme agitation would seem to be the result not of the genocidal decree against her people, but of her embarrassment at his grossly inappropriate appearance amid the opulence of the fortified compound of Susa." Cf. also Carol M. Bechtell, Esther, IBC (Louisville: Westminster John Knox, 2002), 44; Linda Day, Esther, AOTC; Nashville: Abingdon, 2005), 80.

18 For Mordecai's motive of wanting to be heard, see Jonathan Grossman, Esther: The Outer Narrative and the Hidden Reading, Siphrut 6 (Winona Lake, IN: Eisenbrauns, 2011), 112-113.

19 Grossman (Esther, 124-125) states, "it seems that the narrator emphasizes Esther's apparel in order to contrast her with Mordecai, who remains outside the palace gates, fasting, in tattered clothing. ...Esther donned royal garments in order to play the part of queen in her palace, while Mordecai wore sackcloth as he did his part in the city." Cf. Bechtel, Esther, 51.

20 In the Greek addition (D), Esther, along with Mordecai and the Jews, wears sackcloth; she then dons her royal garments when enacting the petition.

21 Day (Esther, 95) comments: "This... is not a fashion statement or a comment specifically about luxurious clothing. ...Esther girds herself with all the power and authority she can muster."

22 On the rhetorical use of the root מלך in Esth 5, see further Levenson, Esther, 89. 
thereby elevating his status. ${ }^{23}$ Indeed, the public spectacle of Esth 6 is tantamount to being, or play-acting, king for a day. ${ }^{24}$

But with what exactly does Haman clothe Mordecai? From idea, to command, to implementation, the royal raiment (לבוּש (סוּם) and and are repeatedly specified (Esth 6:8-11); yet, the crown (כֶ) (כֶ) is only mentioned in Esth $6: 8$ and not reiterated in the following verses. ${ }^{25}$ Syntactically, the crown is subsumed with either Mordecai's raiment or the horse's adornment; but which one? The antecedent of the crown is somewhat ambiguous; for, since Mordecai and the horse are both of masculine declension the first person, masculine, singular pronominal suffix affixed to head (ịּ: Esth 6:8) might apply equally to either. Most scholars understand the horse to be the recipient of the crown; ${ }^{26}$ indeed, Assyrian reliefs show warhorses adorned in precisely this manner. ${ }^{27}$ In the end, "The question of who wears the crown in Esth 6:8 is insignificant since both meanings have identical force. To wear the king's robe and to ride the king's horse signals the great favour in which an individual stands." 28

With Haman there are also instances where a nonliteral donning transpires; and in each case the figurative item evokes a headdress, i.e. something which covers his head or face. The first time Haman's head is veiled ( אָברל וְחָפוּי ראש: Esth 6:12b $\beta$ ) is when, mourning, he dashes home immediately after Mordecai's honouring. What catalysed the mourning which covers Haman's head? Shame and/or humiliation can be inferred (cf. Esth 9:25; cf. also Jer 14:3:

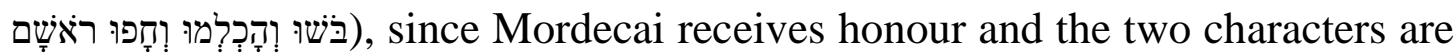

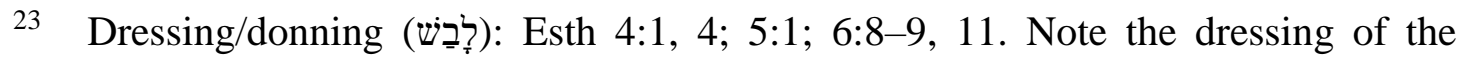
honouree is part and parcel of the honouring act (Esth 6:9).

24 "To wear the kings own clothing...was to have the power of the king himself" (Bechtel, Esther, 59). See also Day, Esther, 110.

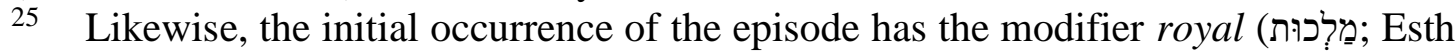
6:8), while every subsequent occurrence simply states the clothing (לְ:? Esth 6:9-11). Nonetheless, increased brevity after the initial full description is standard HB literary convention.

26 E.g. John Screnock and Robert D. Holmstedt, Esther: A Handbook on the Hebrew Text (Waco, TX: Baylor University Press, 2015), 185; Frederic Bush, Ruth/Esther, WBC 9 (Dallas, TX: Word, 1996), 415; Paton, Esther, 248.

27 See Austen Henry Layard, The Monuments of Nineveh The Monuments of Nineveh (London: John Murray, 1853), pls. 14, 21, 22, 23, 27, 57, 64, 72, 80; idem, Discoveries among the ruins of Nineveh and Babylon (New York: Harper \& Brothers, 1853), 499, 527; Henri Frankfort, The Art and Architecture of the Ancient Orient, ed. Nikolaus Pevsner, PHA 27 (Harmondsworth: Penguin, 1954), pls. 84, 88; Georges Perrot and Charles Chipiez, A History of Art in Chaldaea \& Assyria, trans. and ed. Walter Armstrong (London: Chapman and Hall, 1884), 1:45, 269; 2:49, 76, 215.

28 Berg, Esther, 62. Also, the horse could be seen, via metonymy, as a throne: that on which the king sits? 
here polarised. ${ }^{29}$ On the second occasion, the king's accusatory words of judgment, regarding Haman's perceived sexual violation of the queen, cover or

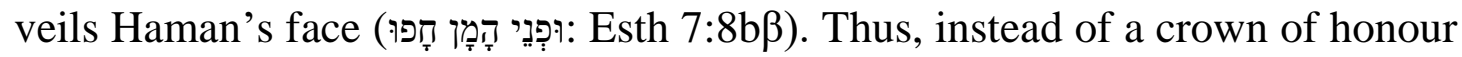
(like Mordecai [in Esth 8:15]), Haman receives a figurative head-covering-a crown, as it were - of shame. Therefore, Haman dons his own head first in a headdress of mourning; and Ahasuerus confers upon Haman the latter's second head-covering, that of accusation.

\section{2d Mordecai}

Mordecai's clothing first comes into focus when he tears (קרבע) it (Esth 4:1aa); considering his official position, these garments were likely semi-distinguished garb. ${ }^{30}$ "By rending his clothes," observes Jonathan Grossman, "Mordecai forfeited his status in Persian society and his station in its regime in order to identify, though nakedness and tatters, with the plight of the Jews." ${ }^{31}$ Next,

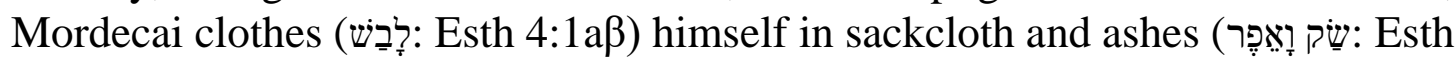

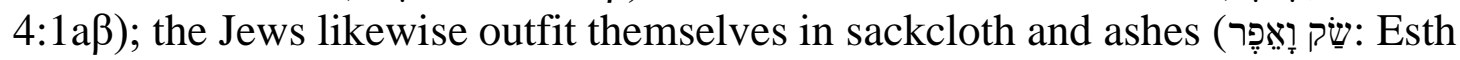
$4: 3 b \alpha)$. This is the signature wear for expressing mourning and grief. ${ }^{32}$

After the honouring episode (Esth 6), Mordecai's clothing vanishes from the narrative. Does he still wear the royal robe, or has he reverted to sackcloth and ashes? It is not stated either way; after the parade, Mordecai simply returned to the king's gate (Esth 6:12a). This location was previously mentioned in reference to his occupation (Esth $2: 19,21 ; 3: 2-3) ; 3$ yet, this is also a locale associated with his lamentation in sackcloth and ashes (Esth 4:2, 6; cf. also Esth $5: 9,13 ; 6: 10)$. Thus, returning to the king's gate, in Esth $6: 12$, may be a way to indicate via metonymy that Mordecai has resumed work and/or reverted to his

29 See Lillian R. Klein, "Honour and Shame in Esther," in A Feminist Companion to Esther, Judith, and Susanna, ed. Athalya Brenner (Sheffield: Sheffield Academic, 1995), 149-75; Timothy S. Laniak, Shame and Honor in the Book of Esther, SBLDS 165 (Atlanta: Scholars Press, 1998).

30 “"Sitting in the palace gate [Esth 2:19]' implies an institutionalized public role" (Grossman, Esther, 76).

31 Grossman, Esther, 112. Grossman (Esther, 115) also observes: "Whereas Mordecai shed his Shushanite garb, Esther sought to reclothe him." For the association of this (lack of) clothing and identity, see Ayelet Seidler, "Jewish Identity on Trial: The Case of Mordecai the Jew," JHebS 17 (2017): 17-21.

32 Sackcloth is always associated with contact with ashes. Ashes are what one sat upon (Job 2:8; Jonah 3:6; cf. Jer 6:26; Isa 58:5) or placed upon one's head (2 Sam 13:19; Ezek 27:30; cf. Isa 61:3). See further, David Lambert, "Fasting as a Penitential Rite: A Biblical Phenomenon?" HTR 96 (2003): 495-96.

33 See again Grossman, Esther, 76; cf. also Robert Gordis, "Studies in the Esther Narrative," JBL 95 (1976): 47-48. 
previous attire of sackcloth and ashes. ${ }^{34}$ Ultimately, it is a matter of reading into silence, or ambiguity.

Through the lens of clothing, the peripety of the book of Esther is signified by Mordecai wearing regal vestments in Esth 8:15. ${ }^{35}$ However, what is elliptic in this passage is the identity of the one who clothes Mordecai; the text simply states: "Then Mordecai went out from the presence of the king, wearing..." (Esth 8:15a NRSV).

\section{The Significance of the One who Clothes Another}

Through systematically examining clothing in the book of Esther as well as the circumstances whereby one undresses or dresses oneself or another gives way to a tentative conclusion: the person who clothes another in better raiment (viz. that of higher and more exclusive quality) is of a higher social standing than the one whom that person is dressing. Thus, it is only the one of inferior social standing that may be elevated by another of higher standing, as represented by clothing. Similarly, in the book of Esther, and perhaps also indicative of the HB in general, someone of lower social standing may only dress oneself laterally to their status or dress-down to signal humiliation.

\section{3a Ahasuerus}

Significantly, it is Ahasuerus who indirectly dresses Mordecai with royal garments in both instances when Mordecai is dressed by another. In Esth 6:1-13 this is done through an intermediary (Haman) at the king's command. In Esth 8:15, while there is syntactical neutrality regarding whether Mordecai clothed himself or was the king's act, the social implication can only infer that Ahasuerus has the status and authority to elevate one by means of attire.

Perhaps it is this intertextual observation which underlies Lewis Paton's comment that Mordecai "is now privileged to wear continually what before he received for a short time only $\left(6^{11}\right) .{ }^{36}$ Whether or not it is the exact same set of clothing as before, the regalia of Esth 8:15 further distinguishes Mordecai from Haman; for, while both ascend to be prime minister (by virtue of wearing the

34 So Michael V. Fox, Character and Ideology in the Book of Esther, $2^{\text {nd }}$ ed. (Grand Rapids: Eerdmans, 2001), 79: "Mordecai simply returns...to his work in the middle echelons of the palace bureaucracy". Seidler ("Mordecai," 18) sees Mordecai's "rending of his garment and refusal to wear the garments sent to him by Esther...reflect an overt and clear attempt to shed the distinctive identifying features of a senior Persian minister..."

35 See Day, Esther, 111 (cf. ibid. 95); Paton, Esther, 279; Fox, Character, 161.

36 Paton, Esther, 279. 
king's signet ring and writing edicts in the king's name), ${ }^{37}$ Haman wished in vain to be honoured by wearing a robe previously worn by the king.

With Haman, it was the king's angry words that covered the former's face, as a veil. This may be seen as an instance of Ahasuerus dressing someone down. ${ }^{38}$ Therefore, Ahasuerus is responsible for the most amount of dressing of another in the book of Esther-albeit this is indirectly and figuratively conveyed.

\section{3b Haman}

Part of the misconception of Haman's fantasy, in Esth 6, is that a noble will elevate Haman by means of adorning him with the king's previously worn regalia. As second-in-command, however, it is rather Haman who will administer the dressing of another; therefore, he - as higher ranking than Mordecai-elevates Mordecai by means of the monarch's recycled raiment. Inversely, Haman dresses himself down, mounting a headdress, as it were, of mourning.

\section{3c Esther}

While Esther can dress herself up in royalty in Esth 5, she nevertheless is the queen and consequently dresses laterally to her status. Provocatively, Esther is unable to elevate Mordecai in Esth 4 by means of clothing; though she is queen, and thereby presumably has the authority to so order, Mordecai refuses the new garments opting instead to remain in sackcloth. Perhaps Mordecai sees Esther not as queen, per se-i.e. someone of higher social standing deserving obeisance-but still as his adopted daughter, and on these grounds can respectably refuse an elevation by means of clothing (cf. Esth 6).

\section{3d Mordecai}

Mordecai only subordinates himself by means of clothing (e.g. Esth 4); it is solely other, higher persons who elevate him with raiment (e.g. Esth 6, 8; contra Esth 4).

\section{PALATIAL MATCHING OF REGALIA}

Mordecai's regal vestments of Esth 8:15 shall now be further investigated. Of particular interest is the way in which Mordecai's last vestments match the palace materials in Esth 1:6. Additionally, it will be shown that the correlation between Ahasuerus's palace and Mordecai's vestments further correlate to the matching between the high priest's garments and the tabernacle. This synchronic

37 Mordecai is "placed by the king in Haman's position," states Paulus Cassel (An Explanatory Commentary on Esther [Edinburgh: T\&T Clark, 1888], 239).

38 Ahasuerus undressing others might be seen in the removal of the signet ring with Haman and the crown with Vashti. 
quadrilateral synthesis purports a diachronic development of royal ideology in Israelite histor(iograph)y.

\section{$1 \quad$ Susa Palace and Mordecai's Vestments}

Scholars recognise how there are "some verbal affinities" between Esth 1:6 and $8: 15,{ }^{39}$ to the extent that Mordecai's "new attire echoes...the palace garden court..." ${ }^{40}$ This is particularly curious considering the possibility that Esth 1:6 may have been a later editorial insertion; for the syntax of the verse is stilted and the narrative would flow seamlessly from Esth 1:5 to 1:7. ${ }^{41}$ Esther 1:6 (NRSv) reads: "There were white cotton curtains and blue hangings tied with cords of fine linen and purple to silver rings and marble pillars. There were couches of gold and silver on a mosaic pavement of porphyry, marble, mother-of-pearl, and coloured stones."

The terms shared between the palace décor and Mordecai's vestments are as follows. ${ }^{42}$

\begin{tabular}{|c|c|c|c|}
\hline \multicolumn{2}{|c|}{ Ahasuerus' Palace (Esth 1:6) } & \multicolumn{2}{|c|}{ Mordecai's Regalia (Esth 8:15) } \\
\hline $\begin{array}{l}\text { white fine linen } \\
\text { and blue wool }\end{array}$ & חוּר כַּרְפַּס וּתְכָלֶת & 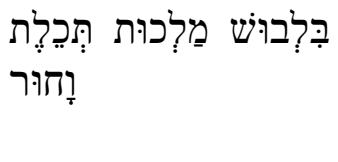 & $\begin{array}{l}\text { royal clothes of } \\
\text { purple wool and } \\
\text { white }\end{array}$ \\
\hline $\begin{array}{l}\text { cords of white } \\
\text { and purple }\end{array}$ & 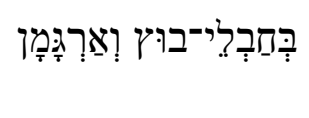 & 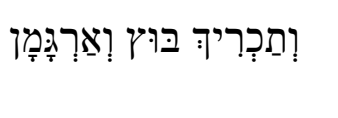 & $\begin{array}{l}\text { a robe of white } \\
\text { and purple }\end{array}$ \\
\hline $\begin{array}{l}\text { couches of gold } \\
\text { and silver }\end{array}$ & מִטּוֹת זָדָב וְכָסֶף & 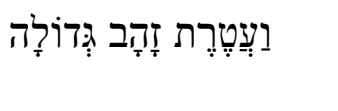 & $\begin{array}{l}\text { a great gold } \\
\text { crown }\end{array}$ \\
\hline
\end{tabular}

In Esth 1:6 there are additional materials described, which would

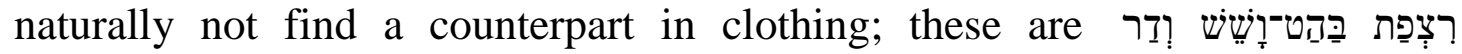
"silver rings and marble pillars...mosaic pavement of porphyry, marble, mother-of-pearl, and coloured stones" (Esth 1:6 NRSV).

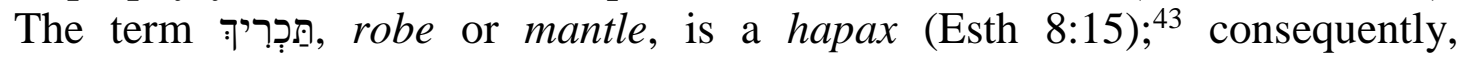
comparative analysis is problematic. ${ }^{44}$ Nevertheless, the above table illustrates

39 Levenson, Esther, 45. See further Paul Haupt, "Critical Notes on Esther," AJSL 24 (1908): 105-06, 161; Screnock and Holmstedt, Esther, 44-47, 224-25.

40 Day, Esther, 139 (cf. ibid., 27).

41 Esther 1:6 "comprises two asyndetic sentences (i.e., no conjunction is used) with highly unusual syntax...parallel in structure", states Bush (Ruth/Esther, 343).

42 Author's translation in textual tables.

43 It is perhaps an Aramaism from כרך, meaning enwrap or the like; cf. BDB, 1067, 510; HALOT 2:1735.

44 Also, חוּר (Esth 1:6; 8:15) finds is a verbal cognate in Isa 29:22 (חור) meaning to grow pale or white; see BDB, 301; HALOT 1:299. 
the correspondence of selectively reserved terms. In fact, the only material repeated elsewhere in the book of Esther, other than the above, is gold (זָזָ): Ahasuerus's golden sceptre (Esth 4:11;5:2; 8:4) and the golden drinking vessels (Esth 1:7).

To reiterate, Ahasuerus's regalia is not mentioned in the book of Esther; yet, his vestments might be extrapolated from the palatial décor. ${ }^{45}$ Thus, it remains possible, and is hereby proposed, that the palace's decoration is a metonymy of the king's wardrobe. ${ }^{46}$ Further, with Mordecai's regalia largely matching the palace in colours and materials, Mordecai's status is somewhat analogous to that of King Ahasuerus. ${ }^{47}$ Could Mordecai hence be presented in Esth 8:15 as a princely figure?

\section{Israelite Kingly Ideology}

Israelite kingly ideology, within the scope of clothing and the sacred structure, shall be juxtaposed with the image of Mordecai in Esth 8:15 as it relates to Esth 1:6. It cannot be concluded whether Israelite kingly apparel had palatial matching, since the only point of comparison is Solomon's laconically described palace in $1 \mathrm{Kgs} 7: 1-12 .{ }^{48}$ Nevertheless, a (polemical?) comparison may still be drawn based on Grossman's observation that both Ahasuerus (in Esth 1) and Solomon (in $1 \mathrm{Kgs} \mathrm{2-3}$ ) hold a lavish banquet for their officials in the third year

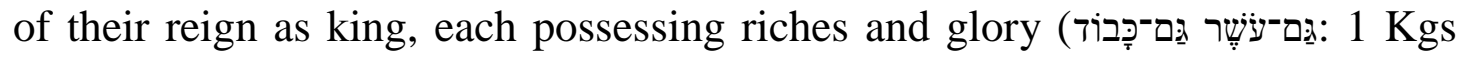

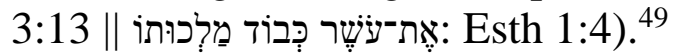

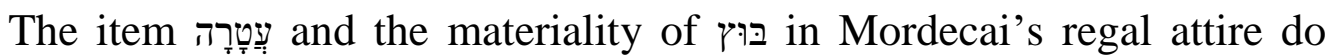
correlate to that worn by Israel's most (in)famous monarchs. ${ }^{50}$ Mordecai's crown

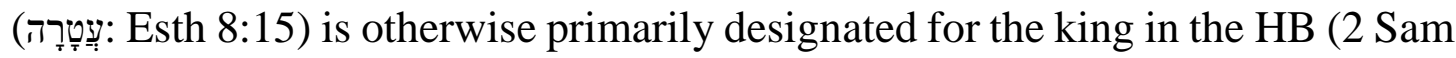

45 Cf. "The noun שש...is a loanword from Egyptian ( $\check{s} s$ ś), which, depending on whether the stone-determinative or the clothing-determinative is used, can either mean 'alabaster' or 'fine linen,' respectively (Screnock and Holmstedt, Esther, 46).

46 If it truly is the king's retired robe (of Esth 6:8) that Mordecai wears in Esth 8:15 (see B $2 \mathrm{~d}$ above), then those vestments do indeed correspond to the materials of the palace.

47 Day (Esther, 139) states that this "subtly suggests that he now also symbolically belongs to the king, just like the palace curtains and royal goblets."

48 See David Ussishkin, "King Solomon's Palaces," BA 36 (1973): 78-105. Cf. also John W. Olley, "Pharaoh's Daughter, Solomon's Palace, and the Temple: Another Look at the Structure of 1 Kings 1-11," JSOT 27 (2003): 355-69. Perhaps the Solomonic Temple could be extrapolated as like unto Solomon's palace; cf. John Van Seters, "Solomon's Temple: Fact and Ideology in Biblical and Near Eastern Historiography," CBQ 59 (1997): 45-57.

49 Grossman, Esther, 42.

50 Day (Esther, 139) cautions, "one should not understand Mordecai's golden garland as showing that he has attained royal status, but instead as a representation of his new wealth and status in the community." 
12:30 // 1 Chr 20:2; Ps 21:4; Song 3:11; Jer 13:18), ${ }^{51}$ namely David (2 Sam 12:30 // $1 \mathrm{Chr}$ 20:2) and Solomon (Song 3:11); in addition, there is a prophetic

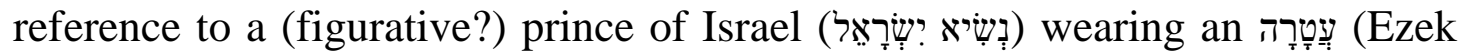
21:30-31 [MT]).

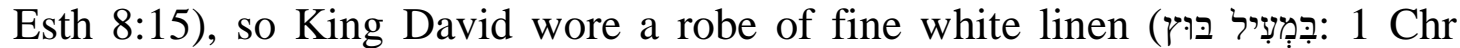
15:27a) when in procession with the ark of the covenant entering Jerusalem; ${ }^{53}$ David was also clad in a linen ephod ( אפוֹד 1 Chr 15:27b). ${ }^{54}$

\section{Tabernacle Décor and High Priestly Vestments}

Analogous to the matching of Mordecai's regalia with Ahasuerus's palatial décor, the $\mathrm{HB}$ attests the correspondence between the high priest's vestments and the tabernacle. ${ }^{55}$ Moreover, a few of the colours and materials common to both the tabernacle and high priest's vestments are also shared with Ahasuerus's palace (Esth 1:6) and Mordecai's regal attire (Esth 8:15). ${ }^{56}$

\begin{tabular}{|l|c|l|}
\hline Tabernacle (with furnishings) & $\begin{array}{l}\text { Esth 1:6; } \\
\mathbf{8 : 1 5}\end{array}$ & High Priest's Regalia \\
\hline Curtains, Loopings and & & Ephod (Exod 28:6, 8; 39:2-3, \\
Covering (Exod 26:1, 4, 31,36; & \multirow{2}{*}{ 5); Breast-piece (Exod 28:15; } & 39:8); Fasteners (Exod 28:28, \\
27:16; 36:8, 11, 35, 37; 38:18) & & $37 ; 39: 21,31$ ); Robe (Exod \\
\hline
\end{tabular}

51 There are many other metaphorical instances as well, such as Job 19:9; 31:36; Prov 4:9; 12:4; 14:24; 16:31; 17:6; Isa 28:1, 3, 5; 62:3; Lam 5:16; Ezek 16:12; 23:42. See also Zech 6:11, 14 below.

52 Cf. Marko Jauhiainen, "Turban and Crown Lost and Regained: Ezekiel 21:29-32 and Zechariah's Zemah," JBL 127 (2008): 501-11.

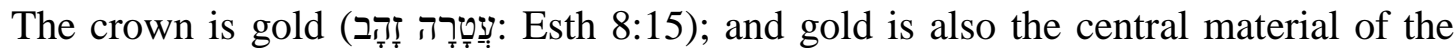
temple (1 Kgs 6:20-22, 28, 30, 32, 35; 7:48-51 // 2 Chr 2:6, 13; 3:4-10; 4:7-8, 19-22; 5:1).

53 코 is rare and only employed in post-exilic material ( $1 \mathrm{Chr} 4: 21 ; 15: 27 ; 2 \mathrm{Chr} 2: 13$; 3:14; 5:12; Esth 1:6; 8:15; Ezek 27:16).

54 The linen ephod is present in (parallel text) 2 Sam 6:14, but not the linen mantle. The curtain of the Solomonic Temple is made, in part, of $\mathrm{Y}$ ( $2 \mathrm{Chr} 3: 14$; cf. $2 \mathrm{Chr}$ 2:13); it is also noteworthy that Levites wearing $\mathrm{Y}$ 크 are part of the procession bringing the Ark of the Covenant inside the First Temple (2 Chr 5:12).

55 See Christophe Nihan, "Le pectoral d'Aaron et la figure du grand prêtre dans les traditions sacerdotales du Pentateuque," in Congress Volume Stellenbosch 2016, eds. Louis Jonker, Gideon Kotzé, and Christl M. Maier, VTS 177 (Leiden: Brill, 2017), $23-$ 55; Menahem Haran, "The Priestly Image of the Tabernacle" HUCA 36 (1965): 191226.

56 Levenson (Esther, 116) has observed, "the garments and colors mentioned in Esth. 8:15 are reminiscent of the vestments of the priesthood (kōhănîm) in the Torah (e.g. Exod. 28:6; cf. 1 Macc. 10:15-20; 59-66). Given the substantial overlap of the royal and the priestly offices in ancient Israel, this is not surprising." Cf. Paton, Esther, 138. 
Spoelstra, “Mordecai’s Royal Vestments," OTE 32/1 (2019): 174-196

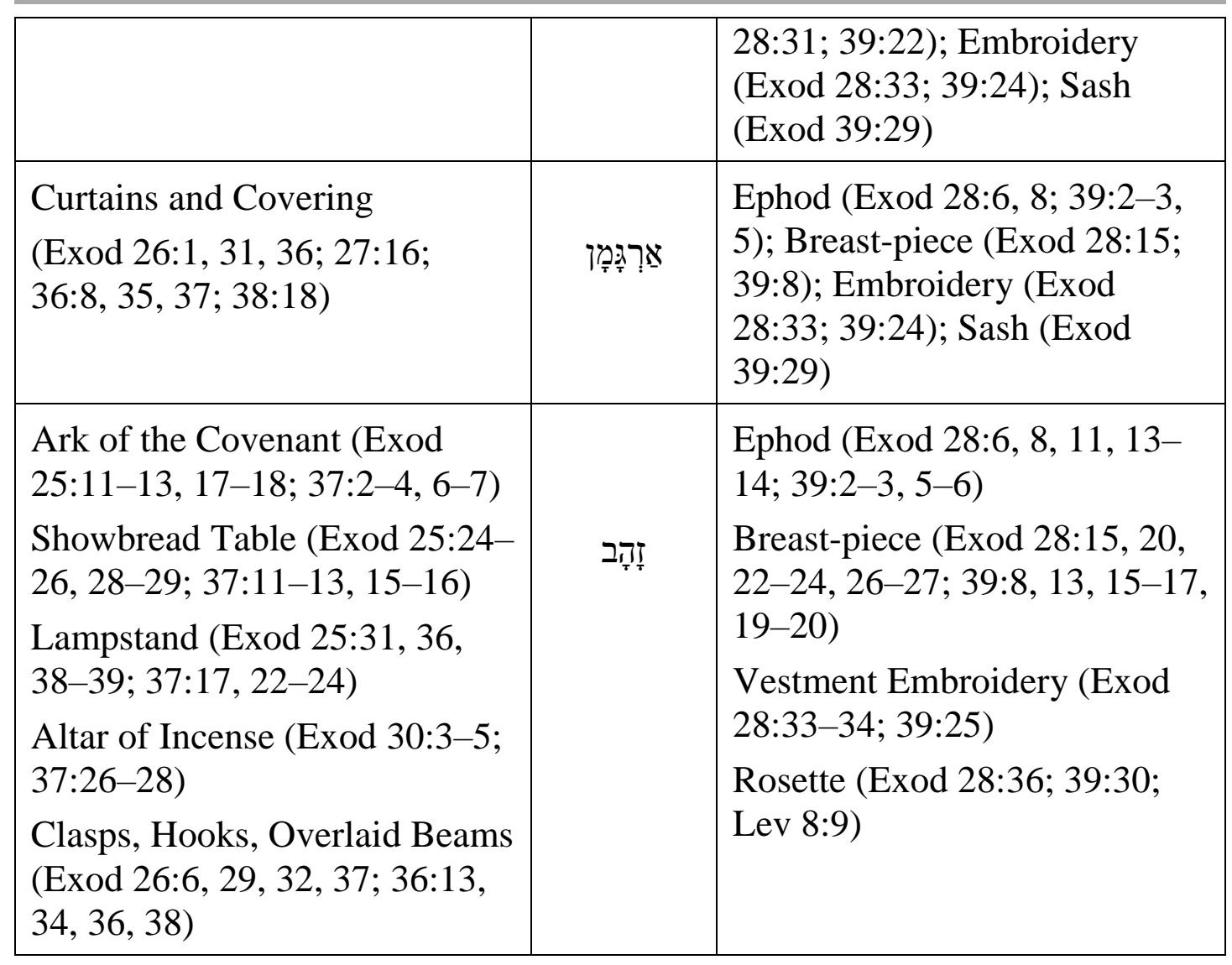

Although there are more connections between the priestly apparel and the sanctuary, the above table demonstrates just those lexical congruities with Esth

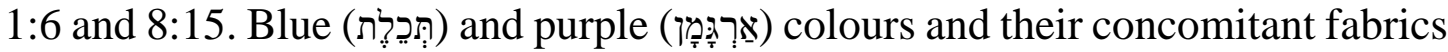
are redolent in both the tabernacle décor and the high priestly vestments; and the golden (זָז) furnishings of the tabernacle are corollary to those of the high priest's regalia. ${ }^{57}$ Thus, not only are the sanctuary curtains like unto the high priest's robes, so also are the tabernacle furnishings and the high priest both crowned with gold.

Interestingly, the gold plate or rosette (NRSV), which bears the inscription holy to $Y H W H$, is fastened to the high priest's turban - and the

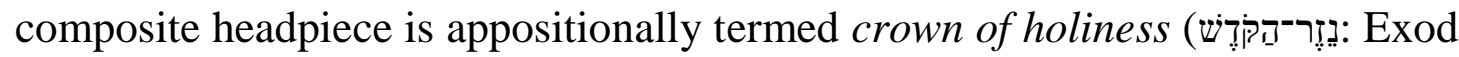
39:30; Lev 8:9). While the crown of Mordecai and the crown of the high priest is made of the same material (gold), the term differs. Still, in a post-exilic vision

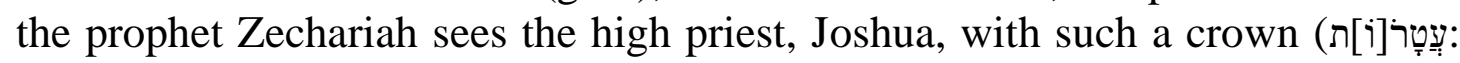
Zech 6:11, 14 || עִָּרָה : Esth 8:15). ${ }^{58}$ Is Mordecai hence portrayed in a priestly visage?

57 Cf. A. Leo Oppenheim, “The Golden Garments of the Gods," JNES 8 (1949): 17293.

58 It is debated how many crowns the text bespeaks and where or on whom the crown(s) is conferred. See e.g. Paul L. Redditt, "Zerubbabel, Joshua, and the Night 


\section{$4 \quad$ Israelite Priestly Ideology}

It has been established that there are several matching colours and materials between Mordecai's royal vestments and the palace materials and how those also correlate to the priestly vestments matching the tabernacle with its articles; in addition, the prominence of dressing others throughout the book of Estherspecifically with Mordecai (לְָָּ: Esth 4:1, 4; 5:1; 6:8-9, 11)—has been underscored. The coalescence of this data makes it worthwhile to call attention to the fact that the priestly dressing/undressing rituals serve as the closest counterpart in the HB; for, as attested in the book of Esther (see B 3 above), in the Pentateuch the person of higher social standing is always the one who elevates a social inferior by means of clothing. ${ }^{59}$ As a result, the Pentateuchal priestly rituals surrounding cultic ceremony further underpin the association of Mordecai being portrayed in a priestly light.

\section{MORDECAI, THE PRINCE AND/OR PRIEST?}

So what exactly is meant by Mordecai's portrayal in regalia (Esth 8:15)? At the very least it is an honorific gesture. Moreover, as previously suggested, there is a synchronic presentation of Mordecai, in the book of Esther, as a princely figure, on the one hand; ${ }^{60}$ on the one hand, when viewing the entire HB, there may be a diachronic development which alludes to Mordecai's garments and accoutrement to those of the high priest and the tabernacle's décor in the Pentateuch. ${ }^{61}$

Concerning Mordecai's princely aspect, a few observations can be extrapolated. To reiterate, the grounds for inquiring the princely aspect of Mordecai lies in the fact that his meticulously detailed royal clothing and

Visions of Zechariah," CBQ 54 (1992): 249-59; Åke Viberg, "An Elusive Crown: An Analysis of the Performance of a Prophetic Symbolic Act (Zech 6:9-15)," SEA 65 (2000): 161-69.

59 The priestly donning motif in the Pentateuch is as follows. Moses is commanded by Yahweh to clothe Aaron as high priest and Aaron's sons as priests in their priestly vestments (לְבְש: Exod 28:41; 29:5, 8; 40:13-14; Lev 8:7, 13). The high priest may perform of series of self-dressing and self-undressing for the rites of the Day of Atonement (לְָָש: Lev 16:4, 23-24, 32). The high priest and Aaronites perform a series of self-dressing and self-undressing for the sacrificial ritual (לְָבְ: Lev 6:3-4). Finally, Num 20 conveys the succession in the high-priestly order, with his death imminent,

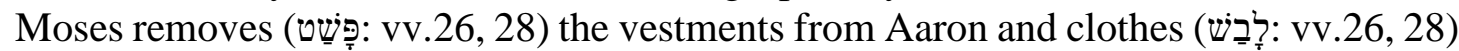
Eliezer with them (cf. also Ezek 42:14; 44:17, 19).

60 Cassel states that Mordecai wears "a princely tiara" (Esther, 240) and is consequently the Jews' "representative and their prince of the captivity" (Esther, 259). 61 Priestly concerns include, for example, Sabbaths, holidays, and festivals; and this is the tenor of the description of Purim in Esth 9; corroborating the books of Esther and Exodus, as Gillis Gerleman has done (Esther, BKAT 21 [Neukirchen: Neukirchener Verlag, 1973]), further undergirds this connection. 
accoutrements are apparently exceptional, over against what Haman achieved or received from King Ahasuerus. ${ }^{62}$ Again, Mordecai becomes second-in-command as represented by being entrusted with the king's signet ring thereby imbued with the authority to write legislation and enforce it (Esth 8). ${ }^{63}$ After the death of Haman and his ten sons, Haman's property is sequestered by Mordecai; ${ }^{64}$ thus, the book of Esther effectively presents Mordecai as the unrivalled successor to the role of prime minister, or grand vizier (Esth 9-10). ${ }^{65}$

Regarding Mordecai's priestly aspect-based on how Mordecai is arrayed in what looks like priestly regalia (according to the textual correlation of Exod 28 and 39) - there are a few actions performed by Mordecai which might connote a priest-like personage. ${ }^{66}$ Like a priest, Mordecai effectively expiates and propitiates by means of mediation; ${ }^{67}$ this is seen in Esth 2:21-23 and Esth 7-9. In both instances there is a murderous plot against a person or group of people (Ahasueurus \|t the Jews), however Mordecai exposes the conspirator(s) (Bigthan and Teresh || Haman) and life is preserved; further, the conspirator(s) are consequently executed by means of impalement (Esth 2:23; 7:10). ${ }^{68}$

62 Although, perhaps such was the attire worn by Haman notwithstanding the narrative silence on the matter. Indeed, parallel statements are registered in the book of Esther along the leitmotif of greatness. Haman is made great (לדָָּ: Esth 3:1; 5:11), as

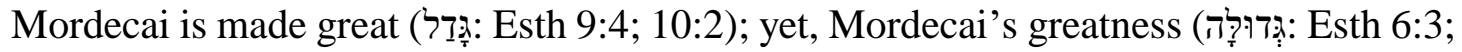
10:3) is again paralleled with Ahasuerus's greatness (aำ: Esth 1:4). Thus, Mordecai's

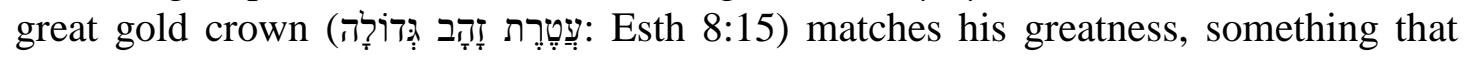
appears to supersede Haman.

63 Seidler ("Mordecai," 22) states, "Mordecai is no longer a minister struggling over his status in the Persian kingdom, but rather the representative of the Jews in the royal court."

64 Cf. again, Day (Esther, 139) who cautions that "one should not understand Mordecai's golden garland as showing that he has attained royal status, but instead as a representation of his new wealth and status in the community."

65 Diachronically, another way in which Mordecai is portrayed in a princely manner is by Mordecai being an ancestor of Israel's first king, Saul (Esth 2:5); cf. Yitzhak Berger, "Esther and Benjaminite Royalty: A Study in Inner-Biblical Allusion," JBL 129 (2010): 625-44. Hence, Mordecai may even be presented as a kinsman redeemer vis-àvis King Saul; cf. Joshua Joel Spoelstra, "Surviving the Agagites: A Postcolonial Reading of Esther 8-9*," OTE 28 (2015): 168-81.

66 Interestingly, Tg. Esth. II relays how when Mordecai emerged from the king's presence, he is received by heralds who are described as "[y]oung people with the crowns of the priests set on their heads, holding trumpets in their hands" (Grossfeld, Targums, 187 [bold and italics original]). The connection between priests and crown in proximity with Mordecai is allusive.

67 See Jacob Neusner, “The Mishnah's Conception of the Priesthood: The Aggadah versus the Halakhah," Temenos 35-36 (1999-2000): 83-101.

68 To nuance this parallel, it must be acknowledged that Esther is part and parcel of these initiatives. It is Esther who discloses the assassination plans for Mordecai; and it 
Therefore, with Mordecai's priest-like vestments, a (retrospective) sacrificial ideology may be evoked in the context of lives being saved at the cost of sacrificial victim(s), thereby nullifying the wrath of the sovereign. ${ }^{69}$

To avoid the either-or fallacy, a both-and consideration ought to be entertained. A hybrid of prince and priest is, in the HB, the composition and vocation of the messiah (see e.g. Ps 110). Is the princely-priestly amalgamation of Mordecai's vestments and personage depicted in terms of a messianic figure? This would be a logical leap, an untenable reading of the book of Esther-even diachronically. ${ }^{70}$ Nevertheless, the conjoining roles of priest and prince in the post-monarchic era do seem to be explored in the post-exilic literature of the HB.

\section{E POST-EXILIC CONSTRUCTIONS OF YEHUDITE LEADERSHIP}

The night visions of the prophet Zechariah (Zech 3-4; 6:9-15) relate to the hybridity or tandem nature of the princely and priestly figure(s) as conjectured in the book of Esther with Mordecai. While the textual integrity and the redactional activity of Zech 1-8 is the subject of much debate and many theories, ${ }^{71}$ it will suffice for our purpose to remark on the TR. Of special interest is (still) the issue of clothing and accoutrements as it relates to the roles of the royal figures of Zech 3-4, and 6:9-15.

The three royal figures are Zerubbabel (Zech 4:6-7, 9-10), governor of Judah/Yehud (Hag 1:1, 14; 2:2, 21), Joshua the high priest (Zech 3:1, 3, 6, 8-9; 6:11), and one Branch ( (צ्? Zech 3:8; 6:12), who is ostensibly a messianic figure (cf. Isa 4:2; Jer 23:5; 33:15). The Branch is a servant of Yahweh (Zech 3:8) who

is Esther who acts of the cryptic directives of Mordecai (Esth 4:13-14) when she exposes Haman's nefarious scheme (after Mordecai first exposes the genocidal threat of the Jews to Esther). Consequently, Mordecai involves - and is even dependent upon-Esther for the fruition his own efforts. Therefore, just as Esther dons regalia to enter the king's presence (Esth 5:1-5), so Mordecai exits the king's presence donned in full regal attire (Esth 8:15); Esther confronted Ahasuerus to begin a process of intercession for her people, while Mordecai departed from Ahasuerus upon the assurance of the preservation of his people's lives.

69 Cf. Berg's discussion regarding one Kish (Esth 2:9) who is a Levite (Esther, 65).

70 See similarly (regarding any would-be messianic complex of Zerubbabel), Janet E. Tollington, Tradition and Innovation in Haggai and Zechariah 1-8, JSOTSupp 150 (Sheffield: Sheffield Academic, 1993), 143.

71 See e.g. Max F. Rogland, Haggai and Zechariah 1-8: A Handbook on the Hebrew Text (Baylor, TX: Baylor University Press, 2016); Lena-Sofia Tiemeyer, Zechariah's Vision Report and Its Earliest Interpreters: A Redaction-Critical Study of Zechariah 18, LHBOTS 626 (London: Bloomsbury, 2016); Michael R. Stead, The Intertextuality of Zechariah 1-8, LHBOTS 506 (London: T\&T Clark, 2009). Cf. also Mark Cameron Love, The Evasive Text: Zechariah 1-8 and the Frustrated Reader, JSOTSupp 296 (Sheffield: Sheffield Academic, 1999). 
will build the temple of Yahweh (Zech 6:12). Zerubbabel is initially declared to be the one who had founded and would finish the temple building in Zech 3:610a, however in Zech 6:9-15 the final construction of the temple is left outstanding and Zerubbabel is conspicuously absent from the vision; ${ }^{72}$ consequently, a future Davidide, whose pseudonym is Branch, is anticipated. ${ }^{73}$ Nonetheless, Zerubbabel is a princely personage, by virtue of being governor of Yehud, a colony of the Persian Empire; and the forthcoming Branch is plausibly a kingly figure, by virtue of being the temple-builder. ${ }^{74}$

Joshua the high priest is portrayed wearing vestments appropriate to the

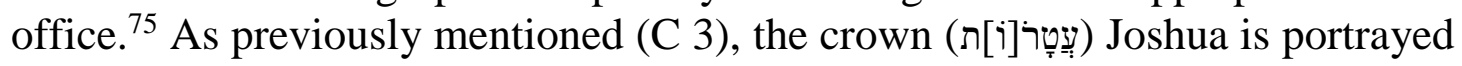
wearing (Zech 6:11, 14) is the same as Mordecai's (Esth 8:15). In the vision Joshua also experiences a priestly undressing/dressing ritual. Joshua's filthy

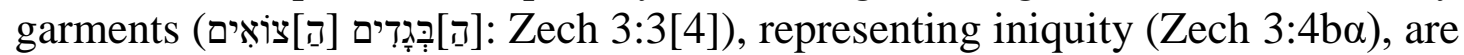

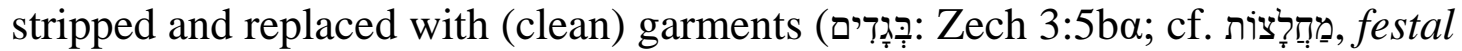

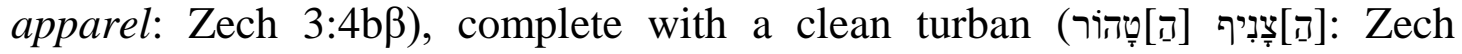
$3: 5 \mathrm{a}[\mathrm{b} \alpha])$.

Curiously, there seems to be in Zech 3-4, 6* both an intentional conceptual assonance with the high priestly image and office as found in the Pentateuch and an intentional literary dissonance with the same tradition lest associations be imported wholesale into the visions of Zechariah. ${ }^{76}$ Furthermore, in Zech 3-4, 6* there is a lack of correspondence between sanctuary fabrics and

72 Tollington (Tradition and Innovation, 172-173) advances the notion that the pseudonym Branch was used to steer attention away from current historical persons, namely Zerubbabel. See also Jean Marcel Vincent, "L'apport de la recherche historique et ses limites pour la compréhension des visions nocturnes de Zacharie," Bib 87 (2006): 30-32.

73 James C. VanderKam, "Joshua the High Priest and the Interpretation of Zechariah 3," CBQ 53 (1991): 554.

74 Paul L. Redditt ("The King in Haggai and Zechariah 1-8 and the Book of the Twelve" in Tradition in Transition: Haggai and Zechariah 1-8 in the Trajectory of Hebrew Theology, eds. Mark J. Boda and Michael H. Floyd, LHBOTS 475 [London: T\&T Clark, 2008], 62) opines Zerubbabel is "the first step toward the restitution of the monarchy."

75 For the alternate titles for high priest in the HB, see Noam Mizrahi, "The History and Linguistic Background of Two Hebrew Titles for the High Priest," JBL 130 (2011): 687-705, esp. 693.

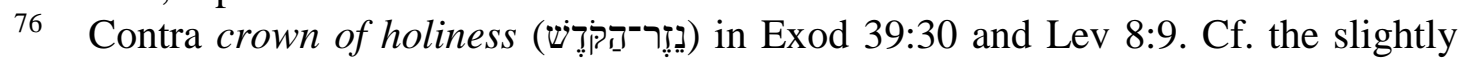

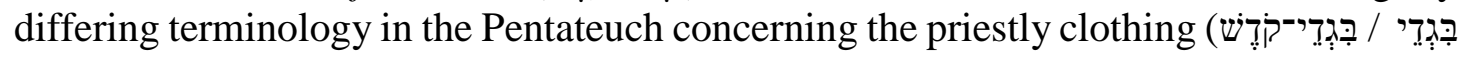

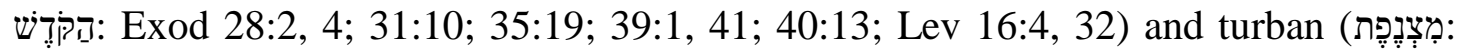
Exod 28:4, 37, 39; 29:6; 39:28, 31; Lev 8:9; 16:4). Also, the seven faceted stone on which Yahweh will engrave an inscription and set it before Joshua (Zech 3:9) is somewhat analogous to other engraved inscriptions of the pre-exilic high priest's vestments and accoutrements $(\operatorname{Exod} 28: 9,11,21 ; 39: 6,14$; cf. Wis 18:24; Sir 45:11). 
materials with the high priestly regalia (save gold [Zech 4:2, 12;6:11]), as is the case in the Pentateuch. What is underscored in the night visions of Zechariah, though, is the diarchic leadership of the princely/kingly and priestly roles. ${ }^{77}$ Joshua appears to receive the crown(s) for, i.e. on behalf of, the forthcoming political ruler. That ruler will sit on his throne, as will the priest sit on a throne; moreover, between the two (offices) will be a council of peace (Zech 6:13). ${ }^{78}$

In the Persian colonial existence of Yehud, a king was not optional; consequently, a princely figure - viz. a governor, like Zerubbabel-was the highest political position. ${ }^{79}$ Nonetheless, in the milieu of the multi-ethnic, multireligious Persian Empire, a priestly figure was able to flourish in association with their (rebuilt) temple, it being permitted and resourced by the imperium. ${ }^{80}$ Thus, the ambiguity of governor and high priest in Zech facilitates a multivalent dialogue for the remnant in its post-exilic era ${ }^{81}$ - principally considering the night visions are "un langage symbolique." 82

Therefore, as it concerns the book of Esther, perhaps Mordecai is literarily portrayed, and henceforth viewed, as a princely-priestly amalgam to the tenor of Joshua and the Branch in Zech 1-6-a figurehead of hope for the post-exilic community. ${ }^{83}$ This too is a symbolic and aspirational postulation, considering that fact that the historicity of the book of Esther is dubious. Ultimately, a definite determination of the significance of Mordecai's regalia cannot be made; nevertheless, its representation may be suggestive of a few options-all intended

77 Mark J. Boda ("Oil, Crowns and Thrones: Prophet, Priest and King in Zechariah 1:7-6:15," JHebS 3 [2001]: 1-35) contends for separate and distinct, yet linked, roles, instead of the priesthood overshadowing the throne.

78 The two sons of oil in Zech 4:14 may be a corollary counterpart (if not identical conceptualisation) to conjoint leadership described in Zech 6:11-13. Redditt ("Night Visions," 257) summarises: "Whether the author thought in terms of a diarchy or merely the absence of strife between the two institutions may remain open."

79 Michael H. Floyd, Minor Prophets: Part 2, FOTL 22 (Grand Rapids: Eerdmans, 2000), 407: "Under the Persians Judah cannot aspire to be a kingdom in the ordinary sense, but Judah can nevertheless aspire to be like a kingdom in the theological sense, i.e., to be the earthly representation of Yahweh's heavenly rule." Emphasis original.

80 Redditt ("The King," 61) maintains that "the building of the temple resulted in the elevation of the priesthood in the absence of any reigning royalty." So also Tollington, Tradition and Innovation, 180; contra Michael Segal, "The Responsibilities and Rewards of Joshua the High Priest according to Zechariah 3:7," JBL 126 (2007): $717-$ 34.

81 See further Antonios Finitsis, Visions and Eschatology: A Socio-Historical Analysis of Zechariah 1-6, LSTS 79 (London: T\&T Clark, 2011), 64-136.

82 Vincent, "Des visions nocturnes de Zacharie," 41.

83 I am not suggesting the audience(s) of Zechariah and the book of Esther were the self-same or knew of the other body of literature; rather, from the perspective of the final-form of the HB canon can such a view emerge. 
to inflame the imagination and inspiration of the possibilities for the Jewish people's open-ended future.

\section{F SUMMARY AND CONCLUSIONS}

The motif of clothing, in the book of Esther, underscores the paralleling, peripety, and progression of characters and events. Stripping off clothing (and accoutrements) represents the divestiture of power; donning of marked clothing (and accoutrements) represents the investiture with power. These results succinctly highlight the composition of Mordecai's regalia, in Esth 8:15, and the multifaceted significance thereof.

Mordecai's regalia ostensibly represents a hybrid of princely (vis-à-vis Ahasuerus's palace) and priestly (vis-à-vis priestly vestments and their correspondence to the tabernacle's materiality) ideology. In the post-exilic era of the Persian period, this imagery was evocative, and the ambiguity or multivocality of the assigned meaning of the regalia is perhaps intentional, indicating open-ended possibilities of the future for (diasporic) Jews upon the liberation of Cyrus. The regalia of Esth 8:15 may perhaps even indicate the anticipated hope of a messiah - that princely-priestly amalgamated figurepotentially also resonant in the post-exilic prophetic literature of Zech 6 .

\section{BIBLIOGRAPHY}

Amit, Yairah. Reading Biblical Narratives: Literary Criticism and the Hebrew Bible. Translated by Yael Lotan. Minneapolis: Fortress, 2001.

Bar-Efrat, Shimon. Narrative Art in the Bible. Translated by Dorothea Shefer-Vanson with S. Bar-Efrat. JSOTSup 70. Sheffield: Almond, 1989.

Batten, Alicia J., Carly Daniel-Hughes and Kristi Upson-Saia, eds. Dressing Judeans and Christians in Antiquity. Burlington, VT: Ashgate, 2014. https://doi.org/ $10.1017 / \mathrm{s} 0075435816000551$.

Bechtell, Carol M. Esther. IBC. Louisville: Westminster John Knox Press, 2002.

Berg, Sandra Beth. The Book of Esther: Motifs, Themes and Structure. SBLDS 44. Missoula, MT: Scholars Press, 1979.

Berger, Yitzhak. "Esther and Benjaminite royalty: a study in inner-Biblical allusion." JBL 129 (2010): 625-44. https://doi.org/10.2307/25765958.

Boda, Mark J. "Oil, Crowns and Thrones: Prophet, Priest and King in Zechariah 1:76:15." JHebS 3 (2001): 1-35.

Brown, Francis, Samuel R. Driver, and Charles A. Briggs. Hebrew and English Lexicon of the Old Testament, with an Appendix Containing the Biblical Aramaic. Peabody, MA: Hendrickson, 2006.

Bush, Frederic. Ruth/Esther. WBC 9. Dallas, TX: Word, 1996.

Cassel, Paulus. An Explanatory Commentary on Esther, with four appendices consisting of the second Targum translated from the Aramaic with notes, Mithra, the winged bulls of Persepolis, and Zoroaster. Edinburgh: T\&T Clark, 1888. https://doi.org/10.1086/470310. 
194 Spoelstra, “Mordecai's Royal Vestments," OTE 32/1 (2019): 174-196

Chan, Michael J. "Joseph and Jehoiachin: On the Edge of Exodus.” ZAW 125 (2013): 566-77.

Cifarelli, Megan and Laura Gawlinski, eds. What Shall I Say of Clothes? Theoretical and Methodological Approaches to the Study of Dress in Antiquity. SPAAA 3. Boston: Archaeological Institute of America, 2017.

Davies, Eryl W. Biblical Criticism: A Guide for the Perplexed. London: Bloomsbury T\&T Clark, 2013.

Day, Linda. Esther. AOTC. Nashville: Abingdon, 2005.

Di Vito, Robert A. “Tradition-Historical Criticism." Pages 90-104 in To Each Its Own Meaning: An Introduction to Biblical Criticisms and their Applications, $2^{\text {nd }}$ ed. Edited by Steven L. McKenzie and Stephen R. Haynes. Louisville: Westminster John Knox, 1999. https://doi.org/10.1177/014610799402400307.

Finitsis, Antonios. Visions and Eschatology: A Socio-Historical Analysis of Zechariah 1-6. LSTS 79. London: T\&T Clark, 2011. . ed. Dress and Clothing in the Hebrew Bible: "For All Her Household Are Clothed in Crimson”. LHBOTS 679. London: Bloomsbury T\&T Clark, 2019.

Floyd, Michael H. Minor Prophets: Part 2. FOTL 22. Grand Rapids: Eerdmans, 2000.

Frankfort, Henri. The Art and Architecture of the Ancient Orient. Edited by Nikolaus Pevsner. PHA 27. Harmondsworth: Penguin, 1954.

Fox, Michael V. Character and Ideology in the Book of Esther. $2^{\text {nd }}$ ed. Grand Rapids: Eerdmans, 2001.

Gerleman, Gillis. Esther. BKAT 21. Neukirchen: Neukirchener Verlag, 1973.

Gordis, Robert. "Studies in the Esther Narrative." JBL 95 (1976): 43-58.

Grossfeld, Bernard. The Two Targums of Esther: Translated, with Apparatus and Notes. ArBib 18. Collegeville, MN: Liturgical Press, 1991.

Grossman, Jonathan. Esther: The Outer Narrative and the Hidden Reading. Siphrut 6. Winona Lake, IN: Eisenbrauns, 2011.

Haupt, Paul. "Critical Notes on Esther.” AJSL 24 (1908): 97-186.

Koehler, Ludwig and Walter Baumgartner. The Hebrew and Aramaic Lexicon of the Old Testament. 2 vols. Leiden: Brill, 2001.

Klein, Lillian R. "Honour and Shame in Esther." Pages 149-75 in A Feminist Companion to Esther, Judith, and Susanna. Edited by Athalya Brenner. Sheffield: Sheffield Academic, 1995. https://doi.org/10.1017/s0364009400006723.

Jauhiainen, Marko. "Turban and crown lost and regained: Ezekiel 21:29-32 and Zechariah's Zemah.” JBL 127 (2008): 501-11. https://doi.org/10.2307/25610136

Jobling, David and Tina Pippin, Ideological Criticism of Biblical Texts. Atlanta: Scholars Press, 1992.

Jonker, Louis C. Exclusivity and Variety: Perspectives on Multidimensional Exegesis. CBET 19. Kampen: Kok Pharos, 1996.

Lambert, David. "Fasting as a Penitential Rite: A Biblical Phenomenon?" HTR 96 (2003): 477-512. https://doi.org/10.1017/s0017816003000531.

Laniak, Timothy S. Shame and Honor in the Book of Esther. SBLDS 165. Atlanta: Scholars Press, 1998.

Layard, Austen Henry. The Monuments of Nineveh. London: John Murray, 1853. 
, Discoveries among the ruins of Nineveh and Babylon. New York: Harper \& Brothers, 1853.

Levenson, Jon D. Esther. OTL. Louisville: Westminster John Knox, 1997.

Love, Mark Cameron. The Evasive Text: Zechariah 1-8 and the Frustrated Reader. JSOTSupp 296. Sheffield: Sheffield Academic, 1999.

Haran, Menahem. "The Priestly Image of the Tabernacle." HUCA 36 (1965): 191-226. Moore, Carey A. Esther. AB 7B. Garden City, NY: Doubleday, 1971.

Mizrahi, Noam. "The History and Linguistic Background of Two Hebrew Titles for the High Priest." JBL 130 (2011): 687-705.

Nihan, Christophe. "Le pectoral d'Aaron et la figure du grand prêtre dans les traditions sacerdotales du Pentateuque." Pages 23-55 in Congress Volume Stellenbosch 2016. Edited by Louis Jonker, Gideon Kotzé and Christl M. Maier. VTS 177. Leiden: Brill, 2017. https://doi.org/10.1163/9789004353893_003.

Neusner, Jacob. "The Mishnah's Conception of the Priesthood: The Aggadah versus the Halakhah." Temenos 35-36 (1999-2000): 83-101. https://doi.org/10.1163/ $157007011 \times 564869$.

Olley, John W. "Pharaoh's Daughter, Solomon's Palace, and the Temple: Another Look at the Structure of 1 Kings 1-11." JSOT 27 (2003): 355-69. https://doi.org/ 10.1177/030908920302700305.

Oppenheim, A. Leo. "The Golden Garments of the Gods.” JNES 8 (1949): 172-93.

Paton, Lewis B. A Critical and Exegetical Commentary on The Book of Esther. ICC. Edinburgh: T\&T Clark, 1976.

Perrot, Georges and Charles Chipiez. A History of Art in Chaldaea \& Assyria. 2 vols. Translated and edited by Walter Armstrong. London: Chapman and Hall, 1884.

Redditt, Paul L. "Zerubbabel, Joshua, and the Night Visions of Zechariah." CBQ 54 (1992): 249-59.

. "The King in Haggai and Zechariah 1-8 and the Book of the Twelve." Pages 56-82 in Tradition in Transition: Haggai and Zechariah 1-8 in the Trajectory of Hebrew Theology. Edited by Mark J. Boda and Michael H. Floyd. LHBOT 475. London: T\&T Clark, 2008. https://doi.org/10.5508/jhs.2010.v10.r46.

Rast, Walter E. Tradition History and the Old Testament. Edited by Gene M. Tucker. GBS. Philadelphia: Fortress, 1972.

Rogland, Max F. Haggai and Zechariah 1-8: A Handbook on the Hebrew Text. Baylor, TX: Baylor University Press, 2016. https://doi.org/10.1111/rsr.13106.

Römer, Thomas. "From Deuteronomistic History to Nebiim and Torah." Pages 1-18 in Making the Biblical Text: Textual Studies in the Hebrew and Greek Bible. Edited by Innocent Himbaza. OBO 275. Fribourg: Academic Press; Göttingen: Vandenhoeck \& Ruprecht, 2015.

Sæbø, Magne. On the Way to Canon: Creative Tradition History in the Old Testament. JSOTSupp 191. Sheffield: Sheffield Academic, 1998.

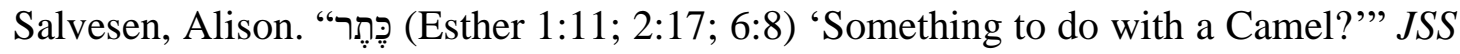
44 (1999): 35-46.

Segal, Michael. "The Responsibilities and Rewards of Joshua the High Priest according to Zechariah 3:7.” JBL 126 (2007): 717-34. https://doi.org/10.2307/27638464. 
196 Spoelstra, “Mordecai’s Royal Vestments," OTE 32/1 (2019): 174-196

Seidler, Ayelet. "Jewish Identity on Trial: The Case of Mordecai the Jew." JHebS 17 (2017): 1-25.

Screnock, John and Robert D. Holmstedt. Esther: A Handbook on the Hebrew Text. Waco, TX: Baylor University Press, 2015.

Spoelstra, Joshua Joel. "Surviving the Agagites: A Postcolonial Reading of Esther 89*." OTE 28 (2015): 168-81. https://doi.org/10.17159/2312-3621/2015/v28 n1a11.

Stead, Michael R. The Intertextuality of Zechariah 1-8. LHBOTS 506. London: T\&T Clark, 2009.

Tiemeyer, Lena-Sofia. Zechariah's Vision Report and Its Earliest Interpreters: A Redaction-Critical Study of Zechariah 1-8. LHBOTS 626. London: Bloomsbury, 2016. https://doi.org/10.5508/jhs.2017.v17.r45.

Tollington, Janet E. Tradition and Innovation in Haggai and Zechariah 1-8. JSOTSupp 150. Sheffield: Sheffield Academic, 1993. https://doi.org/10.1163/156853397 2651405 .

Tolmie, D.F. Narratology and Biblical Narratives: A Practical Guide. London: International Scholars, 1999.

Ussishkin, David. "King Solomon's Palaces.” BA 36 (1973): 78-105. https://doi.org/10.2307/3211070.

Van Seters, John. "Solomon's Temple: Fact and Ideology in Biblical and Near Eastern Historiography." CBQ 59 (1997): 45-57.

VanderKam, James C. "Joshua the High Priest and the Interpretation of Zechariah 3." $C B Q 53$ (1991): 553-70.

Viberg, Åke. "An Elusive Crown: An Analysis of the Performance of a Prophetic Symbolic Act (Zech 6:9-15)." SEA 65 (2000): 161-69.

Vincent, Jean Marcel. "L'apport de la recherche historique et ses limites pour la compréhension des visions nocturnes de Zacharie.” Bib 87 (2006): 22-41.

Walsh, Jerome T. Old Testament Narrative: A Guide to Interpretation. Louisville: Westminster John Knox, 2009.

Rev Dr Joshua Joel Spoelstra, Research Fellow at the Department of Old and New Testament, University of Stellenbosch, Stellenbosch 7600, South Africa. Email: josh.spoelstra@gmail.com; ORCID: https://orcid.org/0000-0001-57021046. 